\title{
Absorption of lactose and its digestion products in the normal and malnourished Ugandan
}

\author{
G. C. COOK, ANNE LAKIN, AND R. G. WHITEHEAD \\ From Mulago Hospital and the Medical Research Council Malnutrition Unit, \\ Kampala, Uganda
}

EDITORIAL COMMENT There is a correlation between the rise in capillary blood glucose and the percentage absorption of lactose following an oral load in normal Ugandan subjects and without lactase deficiency. Lactase deficiency occurs in some children with kwashiorkor.

Primary or specific lactase deficiency is very common in healthy members of the Baganda and other Bantu tribes of Uganda after the first three or four years of life (Cook and Kajubi, 1966; Cook, 19667). Secondary lactase deficiency has been recorded in some cases of kwashiorkor (Bowie, Brinkman, and Hansen, 1965; Stanfield, Hutt, and Tunnicliffe, 1965), where there is mucosal damage in the proximal jejunum. The functional importance of the lactase deficiency in both of these situations is not yet clear.

The lactose-tolerance test has been widely used as a screening test for lactase deficiency and it is important to establish its true value. Several investigators have found a good correlation between the lactase level in specimens of jejunal mucosa and the maximum rise in blood glucose after lactose (Dunphy, Littman, Hammond, Forstner, Dahlqvist, and Crane, 1965; McMichael, Webb, and Dawson, 1965, 1966; Peternel, 1965; Cook and Kajubi, 1966; Welsh, 1966). Others have not found such a good association (Friedland, 1965; Newcomer and McGill, 1966a).

The present study was undertaken to assess the relationship between the rise in capillary blood glucose and percentage absorption of lactose digestion products from the jejunum after oral lactose. By an intubation technique the amount of unabsorbed lactose in the jejunum was measured. In a few subjects jejunal disaccharidase levels were also estimated. Two groups were studied: a series of relatively normal Ugandan hospital patients, and a group of children with mild to moderately severe kwashiorkor.

'Present address: Department of Medicine, The Royal Free Hospital, London, W.C.1.

'Present address: Medical Research Council Dunn Nutritional Laboratory, Infant Nutrition Research Division, University of Cambridge.

\section{MATERIALS AND METHODS}

Thirteen in-patients at Mulago Hospital without clinical evidence of malnutrition or gastrointestinal disease were investigated (Tables I and II).

Five children with kwashiorkor were studied at varying stages of their illness (Table IV). Their ages ranged from 14 to 26 (mean 18.8) months. All were Baganda. The mean body weight on admission to hospital was 8.5 (7.8-9.9) kg. Grading of the severity of kwashiorkor was based on the criteria of Dean (1960).

On the evening before each test, the subjects swallowed a polyvinyl tube ${ }^{3}$ of internal diameter $1.0 \mathrm{~mm}$. in which six holes were cut at the distal end. The tube was threaded through the nose, out of the mouth, and a mercury weight attached before swallowing. The end of the tube was passed to a level which was calculated to be past the area in which most glucose and lactose absorption usually occurs (Hirsch, Ahrens, and Blankenhorn, 1956; Borgström, Dahlqvist, Lundh, and Sjövall, 1957), and its distance from the nasal septum was recorded (Tables I, II, and IV). A straight radiograph of the abdomen was taken before every test to ensure that the tube was not abnormally coiled, and was outlining the normal loops of small intestine. The tolerance tests were performed in the mornings after an eight-hour fast. In all subjects two tests were done on succeeding days, one with lactose and the other with glucose + galactose, both being given as $10 \% \mathrm{~W} / \mathrm{V}$ solutions containing also polyethylene glycol (P.E.G.), molecular weight 4,000, at a concentration of $1 \% \mathrm{~W} / \mathrm{V}$. Lactose tolerance was estimated before glucose + galactose tolerance in all except subjects nos. 6 and 8-13. Capillary blood was taken at $0,30,60,90,120$, and 150 minutes. Samples of jejunal contents were siphoned at 15 -minute intervals, and $5 \mathrm{ml}$. normal saline solution was injected into the tube if intestinal contents did not readily appear. All specimens were immediately frozen solid. Percentage absorption of carbohydrate was calculated according to

'Portex RO1, Portland Plastics Limited, Hythe, Kent, England. 
the method of Dahlqvist and Borgström (1961) and was taken to be the mean of the percentage absorption from all samples of jejunal aspirate containing reducing substance. In four normal subjects, mucosal biopsy was obtained under radiological control from the first or second jejunal loop with the biopsy capsule described by Choudhury, Nicholson, and Cooke (1964). The specimen was immediately divided; part was examined in the fresh state with the dissecting microscope; the remainder was frozen to $-15^{\circ} \mathrm{C}$., and disaccharidases-lactase, sucrase, maltase, and trehalase-were assayed by the method described by Cook and Kajubi (1966). In the kwashiorkor group, 24-hour stools during and after tolerance tests were immediately acidified with $\mathrm{N}$ sulphuric acid, weighed, and the lactic acid content was estimated (Long, 1946; Elsden and Gibson, 1954), using a Markham micro-Kjeldahl apparatus.

Blood glucose was estimated by a glucose-oxidase method (Marks, 1959) and total reducing substance in the jejunal aspirate and stools by the copper-reduction method of Asatoor and King (1954). Polyethylene glycol was estimated according to Hydén (1956) and Jacobson, Bondy, Broitman, and Fordtran (1963).

\section{RESULTS}

CARBOHYDRATE ABSORPTION IN THE NORMAL GROUP Table I shows the results of lactose and glucose + galactose tolerance tests in 10 normal subjects. The mean fasting blood glucose level was $65.6(48-83)$ $\mathrm{mg}$. per $100 \mathrm{ml}$. Mean maximum blood glucose rise after lactose was $16.9(1-35) \mathrm{mg}$. per $100 \mathrm{ml}$. in the Baganda and $33.0(18-51) \mathrm{mg}$. per $100 \mathrm{ml}$. in the subjects from other tribes. The mean maximum rise after glucose + galactose was 43.4 (23-69) $\mathrm{mg}$. per $100 \mathrm{ml}$. The mean percentage absorption was $50 \cdot 8$

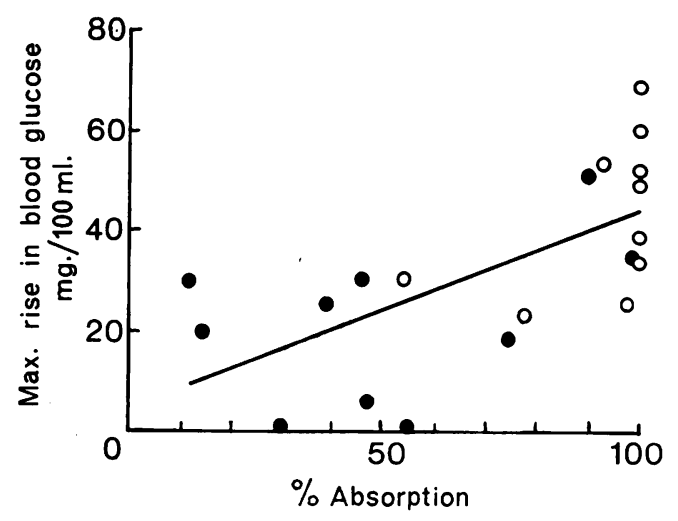

FIG. 1. Correlation between maximum rise in blood glucose (mg. per $100 \mathrm{ml}$.) and percentage absorption of carbohydrate after oral lactose and glucose + galactose in the normal Ugandan subjects. The line represents the calculated regression (percentage absorption $=71.55+$ 1.075 (maximum rise in blood glucose - 32.55); $r=$ $+0.649 ; P<0.01)$.

0 lactose $\bigcirc=$ glucose + galactose .

(12-99) after lactose and 92.3 (78-100) after glucose + galactose. In a 1-year-old Baganda child and two adults from Hamitic tribes who have high lactase activity (Cook and Kajubi, 1966) the percentage absorption of lactose was at least $75 \%$. The correlation between the maximum rise in blood glucose (mg. per $100 \mathrm{ml}$.) and percentage absorption of carbohydrate in the 10 subjects was statistically significant (Fig. 1). The results of duplicate lactose tolerance tests in three normal subjects are shown in

\section{TABLE I}

RESULTS OF LACTOSE AND GLUCOSE + GALACTOSE TOLERANCE TESTS IN 10 NORMAL SUBJECTS

\begin{tabular}{|c|c|c|c|c|c|c|c|c|c|c|c|}
\hline \multirow[t]{2}{*}{$\begin{array}{l}\text { Patient } \\
\text { No. }\end{array}$} & \multirow[t]{2}{*}{$\begin{array}{l}\text { Age } \\
(y r .)\end{array}$} & \multirow[t]{2}{*}{ Sex } & \multirow[t]{2}{*}{ Tribe } & \multirow[t]{2}{*}{ Diagnosis } & \multirow{2}{*}{$\begin{array}{l}\text { Body } \\
\text { Weight } \\
(\text { kg.) }\end{array}$} & \multirow{2}{*}{$\begin{array}{l}\text { Distance } \\
\text { of } \\
\text { Sampling } \\
\text { from } \\
\text { Nasal } \\
\text { Septum } \\
\text { (cm.) }\end{array}$} & \multicolumn{2}{|c|}{$\begin{array}{l}\text { Maximum Glucose } \\
\text { Rise }(\mathrm{mg} . / 100 \mathrm{ml} .)\end{array}$} & \multicolumn{2}{|c|}{ Percentage Absorption } & \multirow{2}{*}{$\begin{array}{l}\text { Diarrhoea } \\
\text { after } \\
\text { - Lactose }\end{array}$} \\
\hline & & & & & & & Lactose $e^{1}$ & $\begin{array}{l}\text { Glucose + } \\
\text { Galactose }^{2}\end{array}$ & Lactose $^{1}$ & $\begin{array}{l}\text { Glucose + } \\
\text { Galactose }\end{array}$ & \\
\hline 1 & $1 \cdot 5$ & $\mathbf{F}$ & Baganda & Pulmonary tuberculosis & $10 \cdot 4$ & 100 & 35 & 25 & 99 & 98 & - \\
\hline 2 & $3 \cdot 5$ & $\mathbf{M}$ & Baganda & Normal & $15 \cdot 0$ & 120 & 25 & 52 & 39 & 100 & - \\
\hline 3 & $5 \cdot 0$ & $\mathbf{M}$ & Baganda & Normal & $19 \cdot 5$ & 120 & 1 & 69 & 55 & 100 & - \\
\hline 4 & $7 \cdot 0$ & $\mathbf{M}$ & Baganda & Normal & $23 \cdot 6$ & 120 & 20 & 49 & 15 & 100 & + \\
\hline 5 & $10 \cdot 0$ & $\mathbf{F}$ & Baganda & Sickle cell disease & $29 \cdot 5$ & 120 & 6 & 60 & 47 & 100 & + \\
\hline $6^{3}$ & $12 \cdot 0$ & $\mathbf{F}$ & Baganda & $\begin{array}{l}\text { Type I nephritis } \\
\text { (convalescent) }\end{array}$ & $43 \cdot 2$ & 130 & 1 & 30 & 30 & 54 & + \\
\hline 7 & $12 \cdot 0$ & $\mathbf{M}$ & Baganda & $\begin{array}{l}\text { Burkitt's lymphoma in } \\
\text { remission }\end{array}$ & $28 \cdot 6$ & 150 & 30 & 53 & 12 & 93 & - \\
\hline $8^{3}$ & 13.0 & $\mathbf{F}$ & $\begin{array}{l}\text { Bahutu } \\
\text { (Rwanda) }\end{array}$ & Idiopathic splenomegaly & $38 \cdot 6$ & 135 & 30 & 39 & 46 & 100 & - \\
\hline 9 & $23 \cdot 0$ & $\mathbf{M}$ & $\begin{array}{l}\text { Batutsi } \\
\text { (Rwanda) }\end{array}$ & Tonsillitis (convalescent) & $63 \cdot 6$ & 145 & 18 & 23 & 75 & 78 & - \\
\hline $10^{3}$ & $17 \cdot 0$ & $\mathbf{M}$ & $\begin{array}{l}\text { Bahima } \\
\text { (Ankole) }\end{array}$ & Rheumatic arthritis & 51.8 & 190 & 51 & 34 & 90 & 100 & - \\
\hline
\end{tabular}


Table II. In nine subjects the peak blood glucose level after lactose was at 30-60 minutes, in two at 90 minutes, and in two at $\mathbf{1 2 0}$ minutes. After glucose + galactose the maximum level was at 30 or 60 minutes in 11 and at 90 minutes in two. Reducing substance in the jejunal fluid was first detected between 30 and 45 minutes in nine subjects; in nos. 2, 6, and 12 it was first found at 15 minutes, and in no. 10 at 90 minutes. Four Baganda had diarrhoea after the lactose tolerance test.

JEJUNAL BIOPSIES IN NORMAL GROUP Table III shows the results of jejunal biopsies and disaccharidase levels. Well-formed leaves were present in all biopsy material. Lactase levels were consistent with the tribal pattern for Uganda described by Cook and Kajubi (1966). Other disaccharidase levels-sucrase, maltase, and trehalase-were within normal limits for a European population (McMichael et al., 1966).

CARBOHYDRATE ABSORPTION IN THE KWASHIORKOR GROUP Table IV shows details of tolerance tests in the five children. The mean fasting blood glucose was $46.3(23-68) \mathrm{mg}$. per $100 \mathrm{ml}$. and the mean maximum rise in blood glucose was $20 \cdot 4(0-50) \mathrm{mg}$. per $100 \mathrm{ml}$. after lactose, and $39.3(8-90) \mathrm{mg}$. per

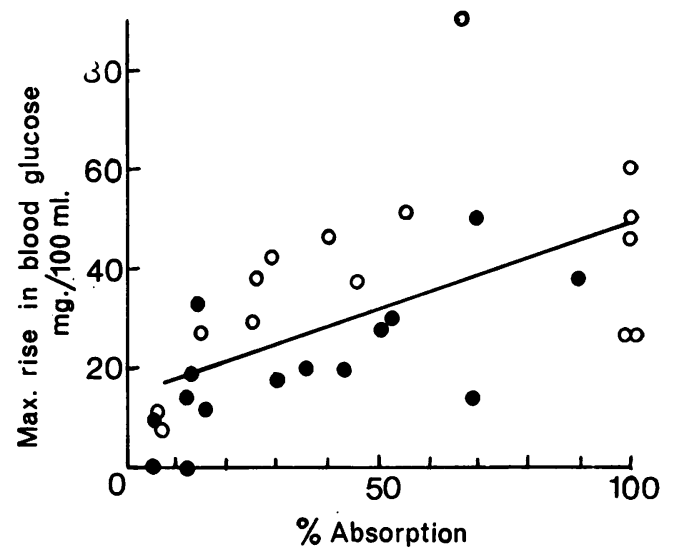

FIG. 2. Correlation between maximum rise in blood glucose ( $\mathrm{mg}$. per $100 \mathrm{ml}$.) and percentage absorption of carbohydrate after oral lactose and glucose + galactose in the children with kwashiorkor. The line represents the calculated regression (percentage absorption $=44.57+$ 2.955 (maximum rise in blood glucose - 29.83); $r=$ $+0.592 ; P<0.001)$.

= lactose $\bigcirc=$ glucose + galactose.

$100 \mathrm{ml}$. after glucose + galactose. The mean percentage absorption was $34 \cdot 7$ (5-90) after lactose, and

TABLE II

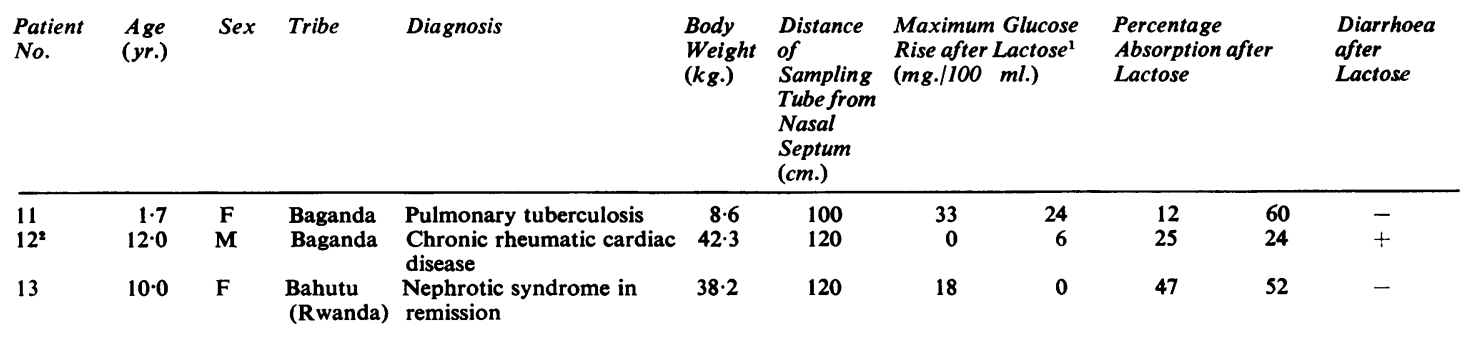

$12 \mathrm{~g} . / \mathrm{kg}$. body weight (maximum $50 \mathrm{~g}$.)

2Jejunal disaccharidases estimated.

TABLE III

JEJUNAL DISACCHARIDASE ESTIMATIONS IN THE NORMAL SUBJECTS ${ }^{1}$

\begin{tabular}{|c|c|c|c|c|c|c|}
\hline \multirow[b]{2}{*}{$\begin{array}{l}\text { Patient } \\
\text { No. }\end{array}$} & \multirow[b]{2}{*}{ Tribe } & \multirow[b]{2}{*}{$\begin{array}{l}\text { Dissecting Microscope } \\
\text { Appearance of Jejunal Biopsy } \\
\text { Specimen }\end{array}$} & \multicolumn{4}{|c|}{ Disaccharidase } \\
\hline & & & Lactase & Sucrase & Maltase & Trehalase \\
\hline $\begin{array}{l}6 \\
8\end{array}$ & $\begin{array}{l}\text { Baganda } \\
\text { Bahutu } \\
\text { (Rwanda) }\end{array}$ & $\begin{array}{l}\text { Thin leaves; no finger villi } \\
\text { Thick leaves; no finger villi }\end{array}$ & $\begin{array}{l}0 \cdot 7 \\
4 \cdot 3\end{array}$ & $\begin{array}{l}15 \cdot 9 \\
10 \cdot 8\end{array}$ & $\begin{array}{l}50 \cdot 8 \\
38 \cdot 1\end{array}$ & $\begin{array}{l}8 \cdot 6 \\
3 \cdot 9\end{array}$ \\
\hline 10 & $\begin{array}{l}\text { Bahima } \\
\text { (Ankole) - }\end{array}$ & Thin leaves; no finger villi & $7 \cdot 5$ & 24.9 & $76 \cdot 2$ & 5.9 \\
\hline 12 & Baganda & Thick leaves; $5 \%$ finger villi & 0.5 & $12 \cdot 1$ & $37 \cdot 6$ & 6.2 \\
\hline
\end{tabular}

${ }^{1} \mathrm{All}$ units expressed as $\mu \mathrm{M}$ disaccharide hydrolysed per $\mathrm{g}$. tissue wet weight per minute at $37^{\circ} \mathrm{C}$. 
TABLE IV

RESULTS OF LACTOSE AND GLUCOSE + GALACTOSE TOLERANCE TESTS IN FIVE CHILDREN WITH KWASHIORKOR

\begin{tabular}{|c|c|c|c|c|c|c|c|c|c|c|}
\hline \multirow[t]{2}{*}{$\begin{array}{l}\text { Child } \\
\text { No. }\end{array}$} & \multirow[t]{2}{*}{$\begin{array}{l}\text { Age } \\
\text { (months) }\end{array}$} & \multirow[t]{2}{*}{$\operatorname{sex}$} & \multirow[t]{2}{*}{$\begin{array}{l}\text { Severity of } \\
\text { Kwashiorkor }\end{array}$} & \multirow{2}{*}{$\begin{array}{l}\text { Initial } \\
\text { Plasma } \\
\text { Protein } \\
(\mathrm{g} . / 100 \mathrm{ml} .)\end{array}$} & \multirow[t]{2}{*}{$\begin{array}{l}\text { Day after } \\
\text { Admission }\end{array}$} & \multirow{2}{*}{$\begin{array}{l}\text { Distance } \\
\text { of } \\
\text { Sampling } \\
\text { from } \\
\text { Nasal } \\
\text { Septum } \\
\text { (cm.) }\end{array}$} & \multicolumn{2}{|c|}{$\begin{array}{l}\text { Maximum Glucose Rise } \\
(\mathrm{mg} . / 100 \mathrm{ml} .)\end{array}$} & \multicolumn{2}{|c|}{ Percentage Absorption } \\
\hline & & & & & & & Lactose $^{1}$ & $\begin{array}{l}\text { Glucose }+ \\
\text { Galactose }\end{array}$ & Lactose $^{1}$ & $\begin{array}{l}\text { Glucose }+ \\
\text { Galactose }^{2}\end{array}$ \\
\hline 1 & 19 & $\mathbf{F}$ & Moderately severe & $4 \cdot 5$ & $\begin{array}{c}1 \& 2 \\
25 \& 26\end{array}$ & $\begin{array}{l}45 \\
45\end{array}$ & $\begin{array}{l}0 \\
0\end{array}$ & $\begin{array}{l}29 \\
11\end{array}$ & $\begin{array}{r}12 \\
5\end{array}$ & $\begin{array}{r}25 \\
6\end{array}$ \\
\hline 2 & 14 & $\mathbf{F}$ & Mild & $3 \cdot 8$ & $\begin{array}{rll}1 & \& 2 \\
15 & \& & 16\end{array}$ & $\begin{array}{l}45 \\
45\end{array}$ & $\begin{array}{l}20 \\
19\end{array}$ & $\begin{array}{l}51 \\
38\end{array}$ & $\begin{array}{l}36 \\
13\end{array}$ & $\begin{array}{l}56 \\
26\end{array}$ \\
\hline 3 & 26 & $\mathbf{F}$ & Moderately severe & $5 \cdot 5$ & $\begin{array}{ccl}2 & \& & 3 \\
14 & \& & 15 \\
16 & \& & 17\end{array}$ & $\begin{array}{l}45 \\
45 \\
80\end{array}$ & $\begin{array}{l}10 \\
33 \\
50\end{array}$ & $\begin{array}{l}27 \\
42 \\
50\end{array}$ & $\begin{array}{r}6 \\
14 \\
70\end{array}$ & $\begin{array}{r}15 \\
29 \\
100\end{array}$ \\
\hline 4 & 17 & $\mathbf{F}$ & Mild & $3 \cdot 6$ & $\begin{array}{rll}1 & \& & 2 \\
3 & \& & 4 \\
21 & \& & 22 \\
23 & \& & 24\end{array}$ & $\begin{array}{l}45 \\
80 \\
45 \\
80\end{array}$ & $\begin{array}{l}12 \\
20 \\
18 \\
30\end{array}$ & $\begin{array}{l}46 \\
60 \\
37 \\
27\end{array}$ & $\begin{array}{l}16 \\
43 \\
30 \\
53\end{array}$ & $\begin{array}{r}40 \\
100 \\
46 \\
100\end{array}$ \\
\hline 5 & 18 & $\mathbf{F}$ & Moderately severe & $5 \cdot 1$ & $\begin{array}{rll}2 & \& & 3 \\
4 & \& & 5 \\
37 & \& & 38 \\
39 & \& & 40\end{array}$ & $\begin{array}{l}80 \\
45 \\
45 \\
80\end{array}$ & $\begin{array}{l}38 \\
28 \\
14 \\
14\end{array}$ & $\begin{array}{r}46 \\
90 \\
8 \\
27\end{array}$ & $\begin{array}{l}90 \\
51 \\
12 \\
69\end{array}$ & $\begin{array}{r}100 \\
67 \\
7 \\
100\end{array}$ \\
\hline
\end{tabular}

$12 \mathrm{~g}$. lactose/kg. body weight.

1 g. glucose +1 g. galactose/kg. body weight.

$54 \cdot 5$ (6-100) after glucose + galactose. The correlation between the maximum rise in blood glucose (mg. per $100 \mathrm{ml}$.) and percentage absorption of carbohydrate after all tests in the five children was statistically significant (Fig. 2). The peak glucose level was late (at 120 or 150 minutes) in five tests after lactose and in three after glucose + galactose. In 20 tests reducing substance was present in the jejunal fluid in the 15-30-minute sample, in six at 30 to 45 minutes, in three at 45 to 60 minutes, and in one at 90 minutes. Moderately severe diarrhoea was present on admission in children nos. 1 and 5 . It was not worsened by lactose. In all children, loose stools were recorded as frequently after glucose + galactose as lactose.

STOOL WEIGHT, LACTIC ACID, AND TOTAL REDUCING SUBSTANCE IN KWASHIORKOR GROUP Table V summarizes the results. The maximum lactic acid excretion in the 24 hours after lactose was $305 \mathrm{mg}$. (equivalent to approximately $3 \%$ of the oral load).

The mean lactic acid excretion after glucose + galactose was slightly greater than that after lactose. The correlation between the 24-hour stool weight and lactic acid excretion was significant $(r=+0.698 ; P<0.001)$. The correlation between stool weight and total reducing substance was also significant $(\mathrm{r}=+0.803 ; \mathrm{P}<0.001)$. No significant alteration in any of these measurements took place during treatment.

\section{DISCUSSION}

There was a good correlation in the normal group

\section{TABLE V}

WEIGHT, LACTIC ACID, AND TOTAL REDUCING SUBSTANCE OF 24-HOUR STOOLS AFTER LACTOSE AND GLUCOSE + GALACTOSE IN THE CHILDREN WITH KWASHIORKOR

\begin{tabular}{|c|c|c|c|c|}
\hline $\begin{array}{l}\text { Tolerance } \\
\text { Test }\end{array}$ & $\begin{array}{l}\text { No. of } \\
\text { Tests }\end{array}$ & $\begin{array}{l}\text { Stool Weight } \\
\text { (g./24 hours) } \\
\text { (Mean and } \\
\text { Range) }\end{array}$ & $\begin{array}{l}\text { Stool Lactic } \\
\text { Acid } \\
\text { (mg./24 hours) } \\
\text { (Mean and } \\
\text { Range) }\end{array}$ & $\begin{array}{l}\text { Total Stool } \\
\text { Reducing } \\
\text { Substance } \\
\text { (mg./24 hours) } \\
\text { (Mean and } \\
\text { Range) }\end{array}$ \\
\hline Lactose $^{1}$ & 15 & $\begin{array}{l}86 \cdot 8 \\
(0-325)\end{array}$ & $\begin{array}{l}53 \cdot 5 \\
(0-305)\end{array}$ & $\begin{array}{l}168 \cdot 5 \\
(0-1,000)\end{array}$ \\
\hline $\begin{array}{c}\text { Glucose }+ \\
\text { galactose }\end{array}$ & 14 & $\begin{array}{l}126 \cdot 9 \\
(0-410)\end{array}$ & $\begin{array}{l}82 \cdot 4 \\
(0-618)\end{array}$ & $\begin{array}{l}260 \cdot 4 \\
(0-1,540)\end{array}$ \\
\hline
\end{tabular}

$12 \mathrm{~g} . / \mathrm{kg}$. body weight.

21 g. glucose +1 g. galactose $/ \mathrm{kg}$. body weight.

and the group of children with mild to moderately severe kwashiorkor between the maximum rise in glucose and percentage absorption of lactose and its constituent monosaccharides. Reproducibility of the method was reasonably good (Tables II and IV). Using a technique similar to that used in the present study, Borgström et al. (1957) showed that approximately $80 \%$ of glucose and lactose had been absorbed in the normal European adult at $150 \mathrm{~cm}$. from the nasal septum. Maximum levels of lactase have been thought to occur in the proximal jejunum (Dahlqvist and Borgström, 1961; Dahlqvist, 1962), although recent evidence (Newcomer and McGill, 1966b) suggests that a high level normally exists in the distal jejunum and ileum also.

In most of the normal subjects there was complete absorption of glucose + galactose. The distal end of the tube was therefore far enough down to be below an area of high monosaccharide absorption. 
In most investigations in the kwashiorkor group, the end of the tube was positioned at $45 \mathrm{~cm}$. from the nasal septum, and in most of these, less than $50 \%$ of the glucose + galactose load was absorbed. When the tube was placed at $80 \mathrm{~cm}$. there was complete absorption. Approximately $50 \%$ of the absorption of monosaccharides in the children with kwashiorkor occurred therefore between 45 and $80 \mathrm{~cm}$. from the nasal septum.

A high incidence of primary lactase deficiency and lactose intolerance in the Baganda tribe (Cook and Kajubi, 1966) has been confirmed. Most of the children with mild or moderately severe kwashiorkor studied in this investigation did not have severely impaired lactose absorption. This was confirmed by the finding of only small amounts of lactic acid and total reducing substance in the stools after the tests. The lactic acid levels in the stools after lactose in the present study were very much lower than in children with established disaccharide intolerance (Weijers, van de Kamer, Dicke, and Ijsseling, 1961). Lactose absorption during the period of treatment was markedly increased in only two children with kwashiorkor.

Four normal Baganda subjects in the present study had clinical lactose intolerance (Anderson, Burke, Messer, and Kerry, 1966), which is a dose-dependent phenomenon, after the lactose load. Diarrhoea after oral lactose in kwashiorkor is well recognized (Dean, 1952), and high stool lactic acid levels after lactose have been reported (Bowie et al., 1965); this is probably, however, a reflection of the severity of the kwashiorkor. It seems likely that those children who get lactose intolerance either have severe kwashiorkor and a grossly damaged jejunal mucosa with severe secondary disaccharidase deficiency, or an early onset of primary (specific) lactase deficiency which has been shown to occur in Baganda infants (Cook, 1967).

Low jejunal lactase activity is very common in children who have recovered from mild to very severe kwashiorkor (Cook and Lee, 1966); it has been demonstrated in both Baganda and Bahutu (Rwanda) children after kwashiorkor. In Baganda children this is likely to be a result of the fall in lactase activity which normally occurs in the first three to four years of life and is probably genetically determined (Cook, 1967). Some, but not all, members of the Bahutu (Rwanda) tribe have lactase deficiency in adult life (Cook and Kajubi, 1966); the reason why children from that tribe all have low lactase levels after recovery from kwashiorkor of varying grades of severity is not clear. In view of the present findings it does not seem to be a result of mucosal damage during kwashiorkor, because the children studied in this investigation with mild to moderately severe kwashiorkor did not have a high incidence of lactase deficiency. It seems more likely that individuals, from either tribe, who will show a fall in lactase activity during infancy (Cook, 1967) are in some way predisposed to kwashiorkor. The mechanism of this is not clear.

\section{SUMMARY}

A good correlation has been found between the maximum rise in capillary blood glucose levels and the percentage absorption of carbohydrate (measured by estimating carbohydrate levels in the jejunum) during oral lactose and glucose + galactose tolerance tests.

Lactase deficiency and defective lactose absorption have been confirmed in normal Baganda subjects. Five children with mild to moderately severe kwashiorkor had less severely impaired lactose absorption.

Lactic acid and total reducing substance were estimated in the stools of the children with kwashiorkor during and after the tolerance tests; only small amounts were found.

We are indebted to the late Professor R. F. A. Dean for suggesting the investigation in the children with kwashiorkor. We are grateful to the nursing staff of Mulago Hospital and the M.R.C. Malnutrition Unit for help with the patients; to Mr. P. G. Ward for technical help with the stool analyses; and to Professor R. A. McCance, F.R.S. for reading the manuscript and for helpful suggestions.

\section{REFERENCES}

Asatoor, A. M., and King, E. J. (1954). Simplified colorimetric blood sugar method. Biochem. J., 56, $44 \mathrm{P}$.

Anderson, C. M., Burke, V., Messer, M., and Kerry, K. R. (1966). Sugar intolerance and coeliac disease. Lancet, 1, 1322.

Borgström, B., Dahlqvist, A., Lundh, G., and Sjövall, J. (1957). Studies of intestinal digestion and absorption in the human. J. clin. Invest., 36, 1521-1536.

Bowie, M. D., Brinkman, G. L., and Hansen, J. D. L. (1965). Acquired disaccharide intolerance in malnutrition. J. Pediat., 66, 10831091.

Choudhury, D. C. R., Nicholson, G. I., and Cooke, W. T. (1964). Simple capsule for multiple intestinal biopsy specimens. Lancet, 2, 185-186.

Cook, G. C. (1967). Lactase activity in newborn and infant Baganda. Brit. med. J., 1, 527-530.

—, and Kajubi, S. K. (1966). Tribal incidence of lactase deficiency in Uganda. Lancet, $1,725-730$.

, and Lee, F. D. (1966). The jejunum after kwashiorkor. Ibid., 2, 1263-1267.

Dahlqvist, A. (1962). Specificity of the human intestinal disaccharidases and implications for hereditary disaccharide intolerance. $J$. clin. Invest., 41, 463-470.

accharides in man. Biochem. J., 81, 411-418.

Dean, R. F. A. (1952). The treatment of kwashiorkor with milk and vegetable proteins. Brit. med. J., 2, 791-796.

(1960). Treatment of kwashiorkor with moderate amounts of protein. J. Pediat., 56, 675-689. 
Dunphy, J. V., Littman, A., Hammond, J. B., Forstner, G., Dahlqvist, A., and Crane, R. K. (1965). Intestinal lactase deficit in adults. Gastroenterology, 49, 12-21.

Elsden, S. R., and Gibson, Q. H. (1954). The estimation of lactic acid using ceric sulphate. Biochem. J., 58, 154-158.

Friedland, N. (1965). 'Normal' lactose tolerance test. Arch. intern. Med., 116, 886-888.

Hirsch, J., Ahrens, E. H., Jr., and Blankenhorn, D. H. (1956). Measurement of the human intestinal length in vivo and some causes of variation. Gastroenterology, 31, 274-284.

Hydén, S. (1956). A turbidimetric method for the determination of higher polyethylene glycols in biological materials. $K$. LantbrHögsk. Annlr., 22, 139-145.

Jacobson, E. D., Bondy, D. C., Broitman, S. A., and Fordtran, J. S. (1963). Validity of polyethylene glycol in estimating intestinal water volume. Gastroenterology, 44, 761-767.

Long, C. (1946). The stabilization and estimation of lactic acid in blood samples. Biochem. J., 40, 27-33.

Marks, V. (1959). An improved glucose-oxidase method for determining blood, C.S.F. and urine glucose levels. Clin. chim. Acta, 4, 395-400.
McMichael, H. B., Webb, J., and Dawson, A. M. (1965). Lactase deficiency in adults. A cause of 'functional' diarrhoea. Lancet, $1,717-720$.

$-, \ldots,-(1966)$. Jejunal disaccharidases and some observations on the cause of lactase deficiency. Brit. med.J., 2, 1037-1041.

Newcomer, A.D., and McGill, D. B. (1966a). Lactose tolerance tests in adults with normal lactase activity. Gastroenterology, 50, 340-346.

- $-1966 \mathrm{~b})$. Distribution of disaccharidase activity in the small bowel of normal and lactase-deficient subjects. Ibid., 51, 481-488.

Peternel, W. W. (1965). Lactose intolerance in relation to intestinal lactase activity. Ibid., 48, 299-306.

Stanfield, J. P., Hutt, M. S. R., and Tunnicliffe, R. (1965). Intestinal biopsy in kwashiorkor. Lancet, 2, 519-523.

Weijers, H. A., van de Kamer, J. H., Dicke, W. K., and Ijsseling, J. (1961). Diarrhoea caused by deficiency of sugar splitting enzymes I. Acta paediat. (Uppsala), 50, 55-71.

Welsh, J. D. (1966). On the lactose tolerance test. Gastroenterology, 51, 445-446.

\section{The October 1967 Issue}

\section{THE OCTOBER 1967 ISSUE CONTAINS THE FOLLOWING PAPERS}

Obituary: Henry A. Magnus F. AVERY JONES

Hepatic scintillography E. A. JONES

Pancreatic scanning IAN A. D. BOUCHIER

Rectal biopsy as an aid to cancer control in ulcerative colitis B. C. MORSON and LILLIAN S. C. PANG

Primary sclerosing cholangitis, the biliary tree, and ulcerative colitis M. E. C. THORPE, P. J. SCHEUER, and SHEILA SHERLOCK

Studies on the familial incidence and clinical history of patients with chronic unconjugated hyperbilirubinaemia PAUL M. SMITH, J. E. MIDDLETON, and ROGER WILLIAMS

Zinc and manganese levels in serum and liver after alcohol feeding and development of fatty cirrhosis in rats ANTHONY J. BARAK, HARRIET C. BECKENHAUER, and FELIX J. KERRIGAN

Observations on oral betamethasone-17-valerate in the treatment of idiopathic steatorrhoea: A. T. OTAKI, J. R. DALY, and A. MORTON-GILL

Motor responses of the human alimentary tract to nearmaximal infusions of penta-gastrin J. J. MISIEWICZ, D. J. HOLDSTOCK, and SHEILA L. WALLER
Analysis of the motor effects of gastrin and pentagastrin on the human alimentary tract in vitro A. BENNETT, J. J. MISIEWICZ, and SHEILA L. WALLER

Gastric response to subcutaneous injection of a gastrinlike pentapeptide K. G. WORMSLEY, M. P. MAHONEY, and G. KAY

Serum proteins in ulcerative colitis: electrophoretic patterns in the inferior mesenteric artery and vein F. T. de DOMBAL

Changes in the motility of the small intestine in digestive disorders F. PIRK

Histochemistry of the colonic epithelial mucins in normal subjects and in patients with ulcerative colitis V. GRECO, G. LAURO, A. FABBRINI, and A. TORSOLI

The antrum in patients with duodenal and gastric ulcers J. SCHRAGER, R. SPINK, and S. MITRA

Limitation of the use of inert gases in the measurement of small gut mucosal blood flow J. D. HAMILTON, A. M. DAWSON, and JOAN WEBB

Gastroenterological Society of Australia

Copies are still available and may be obtained from the PUBLISHING MANAGER

BRITISH MEDICAL ASSOCIATION, TAVISTOCK SQUARE, W.C.1, price 18s. 6D. 